\title{
Primary "Botryoid" Embryonal Rhabdomyosarcoma in Mesentery
}

\author{
Mezenter'de Primer "Botryoid" Embriyonel Rabdomyosarkom
}

\author{
Kiran AGARWAL, Ruchika KUMAR GOEL, Vandana PURI
}

Department of Pathology, Lady Hardinge Medical College, NEW DELHI, INDIA

\begin{abstract}
Rhabdomyosarcoma is a soft tissue neoplasm arising from primitive embryonal mesenchyma. Embryonal rhabdomyosarcoma mostly affects children younger than 10 years of age, but it also occurs in adolescents and young adults. Pleomorphic rhabdomyosarcoma is a rare variant that almost always arises in adults older than 45 years of age. Mesentery is a rare site for botyroid embryonal rhabdomyosarcoma and on extensive search we found only one case of a botryoid rhabdomyosarcoma in a child of 2 years. We report a rare case of botyroid embryonal rhabdomyosarcoma occurring in the mesentery of a 30 year old female.
\end{abstract}

Key Words: Embryonal rhabdomyosarcoma, Mesentery, Adult, Soft tissue neoplasms
ÖZ

Rabdomyosarkom, primitif embriyonel mezenkimden kaynaklanan bir yumuşak doku neoplazmıdır.Embriyonel rabdomyosarkom çoğunlukla 10 yaşından küçük çocukları etkiler, ancak aynı zamanda ergenlerde ve genç erişkinlerde de ortaya çıar. Pleomorfik rabdomyosarkom, hemen her zaman 45 yaş üzerindeki yetişkinlerde ortaya çıkan nadir bir varyanttır. Mezenter, botyroid embriyonel rabdomyosarkom için nadir bir yerleşim alanıdır ve yoğun araştırmalar sonucunda 2 yaşındaki bir çocukta gelişen sadece bir botryoid rabdomyosarkom olgusu bulduk. 30 yaşındaki kadın hastanın mezenterinde oluşan nadir bir botyroid embriyonel rabdomyosarkom olgusunu sunuyoruz.

Anahtar Sözcükler: Embriyonal rabdomyosarkom, Mezenter, Erişkin, Yumuşak doku neoplazmları

\section{INTRODUCTION}

Rhabdomyosarcoma is a soft tissue neoplasm arising from primitive embryonal mesenchyma. Embryonal rhabdomyosarcoma mostly affects children younger than 10 years of age, but it also occurs in adolescents and young adults. Pleomorphic rhabdomyosarcoma is a rare variant that almost always arises in adults older than 45 years of age (1). The mesentery is a rare site for botyroid embryonal rhabdomyosarcoma and on extensive search we found only one case of a botryoid rhabdomyosarcoma in a child of 2 years (2).

We report a rare case of botyroid embryonal rhabdomyosarcoma occurring in the mesentery of a 30year-old female.

\section{CASE REPORT}

A 30-year-old female presented with a rapidly increasing abdominal lump for the last month. The patient did not have any major bladder or bowel complaints, fever, bleeding or

Received : 12.02 .2010

Accepted : 28.04 .2010 loss of weight. Clinical examination revealed a single intra abdominal lump, occupying the whole abdomen. There was no lymphadenopathy. The chest and cardiovascular examination was within normal limits.

CECT abdomen revealed an $18 \times 18 \mathrm{~cm}$ bosselated fleshy mass arising from the root of the mesentery, adherent to the transverse colon and great vessels. The features were suggestive of a lymphoma/gastrointestinal stromal tumor.

An incisional biopsy was done. The mass was too large and adherent for a complete resection.

In gross examination, we received two unencapsulated soft tissue pieces. The larger piece measured $10 \times 5 \times 3 \mathrm{~cm}$ and the smaller piece $6 \times 3.5 \times 1 \mathrm{~cm}$. Their cut surface was grey-white and fleshy with focal gelatinous and hemorrhagic areas (Figure 1).

Hematoxylin and eosin microsections revealed an unencapsulated tumor with hypo- and hypercellular areas. The hypocellular areas were composed of haphazardly

Correspondence: Ruchika KUMAR GOEL

Department of Pathology, Lady Hardinge College, NEW DELHI, INDIA

E-mail: dr.ruchikagoel@gmail.com Phone: 5322410974 
arranged tumor cells dispersed in myxoid stroma (Figure 2). These tumor cells were round to oval to spindle shaped with moderate eosinophilic cytoplasm and round to oval nuclei with coarse chromatin and inconspicuous nucleoli. Few strap and tadpole cells were scattered throughout the tumor. A peripheral zone of increased cellularity consistent with the cambium layer was also seen (Figure $3,4)$. Hypercellular areas consisted of haphazardly arranged spindle cells showing moderate pleomorphism and cytological atypia and constituted less than $10 \%$ of the entire tumor examined (Figure 5). Scattered throughout the tumor were many rhabdomyoblasts. Foci of hemorrhage and necrosis were seen.

Considering these histological features, a provisional diagnosis of botyroid embryonal rhabdomyosarcoma was made.

An immunohistochemical panel was set up. Tumor cells were positive for Vimentin, Desmin (Figure 6A), and Myogenin (Figure 6B) and showed focal positivity with Smooth muscle actin. They were negative for CD117 and S100 . Hence a final diagnosis of primary botyroid embryonal rhabdomyosarcoma was made.

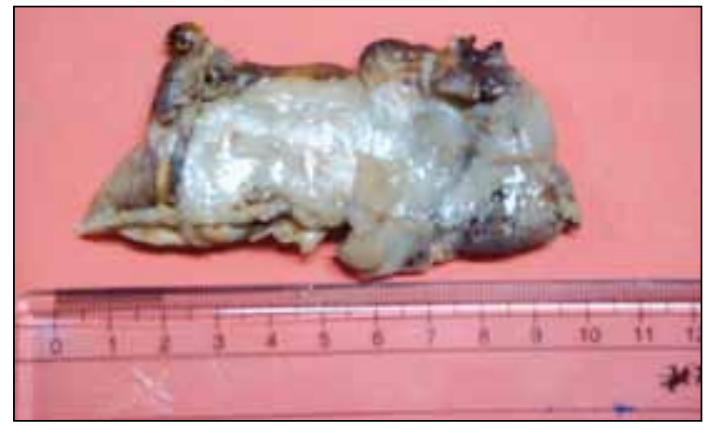

Figure 1: Unencapsulated soft tissue; grey white, fleshy with focal gelatinous and hemorrhagic areas.

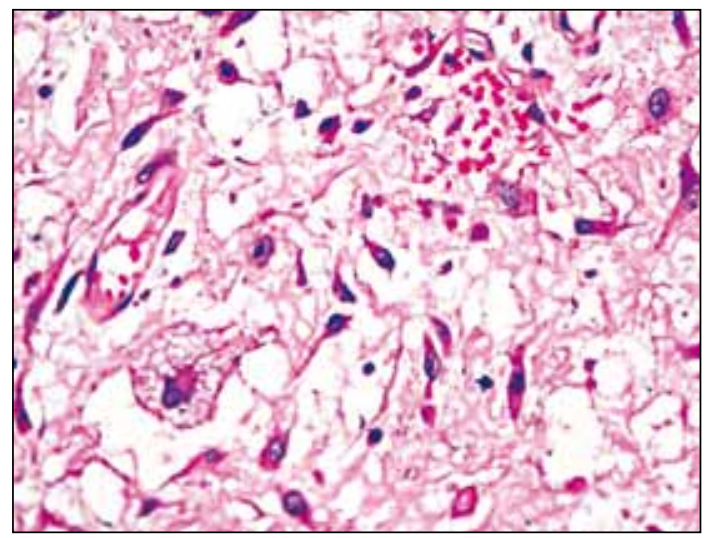

Figure 2: Hypocellular area (H\&E; x400).

\section{DISCUSSION}

Rhabdomyosarcoma has been broadly grouped into 4 histological subtypes: embryonal, alveolar, pleomorphic and mixed (3). Embryonal rhabdomyosarcoma accounts for $60 \%$ of childhood rhabdomyosarcoma and is most frequently seen in soft tissues of the head and neck followed by the genitourinary tract. However, the proximal

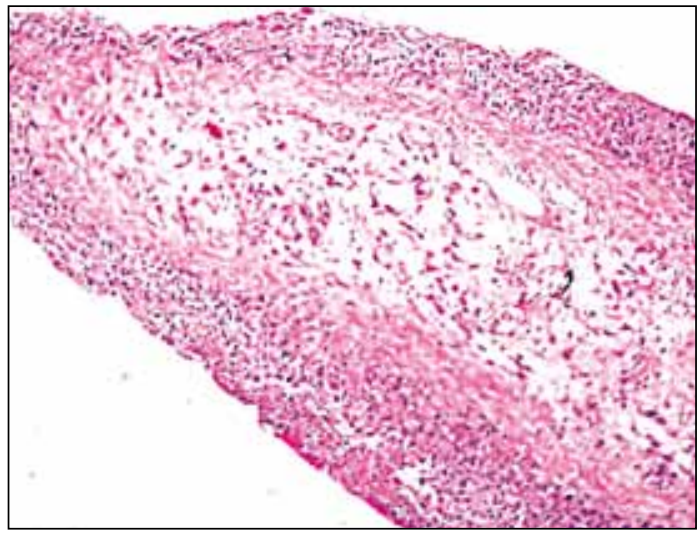

Figure 3: Cambium layer (H\&E; x100).

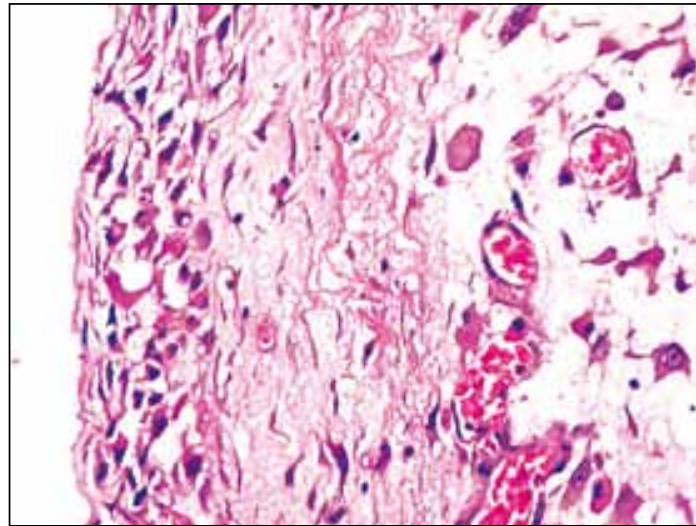

Figure 4: Cambium layer with hypocellular areas (H\&E; x200).

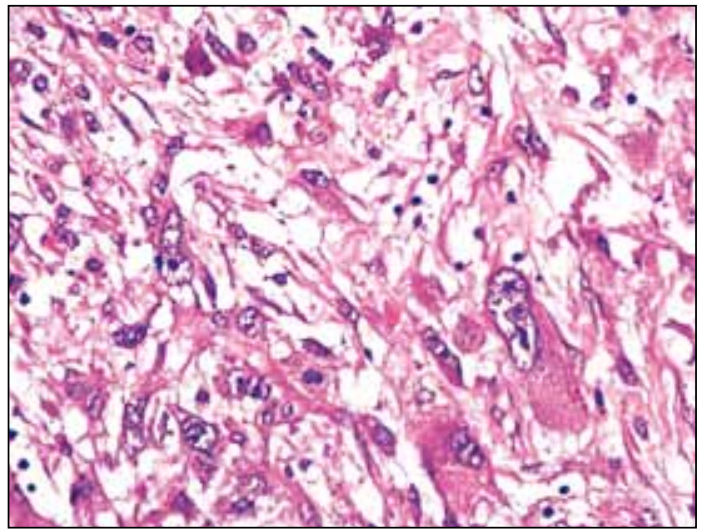

Figure 5: Hypercellular areas showing pleomorphism (H\&E; x400). 

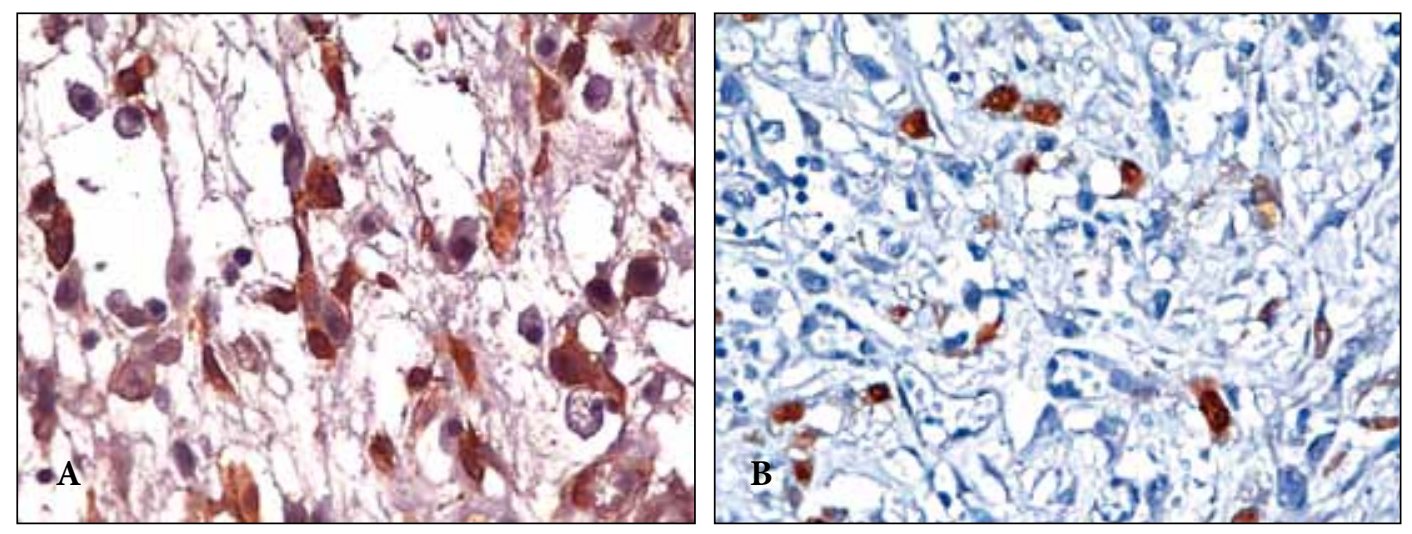

Figure 6: Tumor cells showing desmin, A) and myogenin positivity B) (x400). part of extremities and genitourinary tract are involved more commonly that the head and neck region in adults (4). Embryonal rhabdomyosarcoma has been further subdivided as myxoid, round, botyroid and spindle cell types (1).

Botyroid rhabdomyosarcoma cases account for almost $6 \%$ of all rhabdomyosarcomas and are described predominantly in the mucosa-lined hollow visceral organs such as the nasopharynx, nasal cavity, bile duct, urinary bladder and vagina; the cases are usually less than 5 years of age (1). The mesentery is a rare site for rhabdomyosarcoma and only four cases have been described so far, all with an alveolar histology. Only one case of primary botyroid rhabdomyosarcoma in the mesentery of a 2-year-old child has been described (2). The index case is a primary botyroid rhabdomyosarcoma located in the mesentery of a 30-yearold female that revealed a cellular, solid, well-encapsulated gross morphology instead of a polypoidal mass.

The differential diagnoses in the present case were myxoid liposarcoma and myxoid peripheral nerve sheath tumor. The presence of a cambium layer and strong positivity for desmin, vimentin and myogenin aided in the diagnosis of a botyroid embryonal rhabdomyosarcoma.

The primary site of rhabdomyosarcoma is an important prognostic determinant. In adults, neoplasms arising in the genitourinary organs and extremities have a better prognosis compared to tumors of the head and neck region but it is considered worse than that of their pediatric counterparts (5). Other favourable prognostic factors reported are young age (infants and children), size of tumor $(<5 \mathrm{~cm})$, botyroid or spindle type, localized disease and complete initial resection $(1,6)$. Hematogenous and lymphatic metastasis occurs rapidly in these tumors.

Multimodality treatments have improved survival in children; however, the prognosis in adults is still dismal. Embryonal rhabdomyosarcomas are moderately radiosensitive tumors. A radiation dose of $40 \mathrm{~Gy}$ to a wide local region and 5-15 Gy boost irradiation is adequate for local control (7). The patient was referred for radiotherapy and was lost to follow up.

This case is presented because of its rare site: a botyroid type morphology occurring as a solid tumor at an extra luminal site in an adult. To the best of our knowledge our case appears to be the first reported case of primary botyroid embryonal rhabdomyosarcoma arising in the mesentery of an adult female. It is therefore important to identify botyroid type rhabdomyosarcoma because of its favorable prognosis.

\section{REFERENCES}

1. Weiss SW, Goldblum JR: Rhabdomyosarcoma. In Weiss SW, Goldblum JR (eds). Enzinger and Weiss's soft tissue tumors. 4th ed., St. Louis, CV Mosby, 2001, 785-835

2. Agarwal K, Kulshrestha R, Pahuja S, Chadha R: Botyroid rhabdomyosarcoma of mesentery-a case report. Indian J Pathol Microbiol 2003, 46:457-459

3. Jund R, Leunig A, Hagedorn H, Nerlich A, Grevers G: Embryonal rhabdomyosarcoma of the nose in an elderly patient, case reported and review of literature. Auris Nasus Larynx 1998, 25:445-450

4. Hardaway CA, Graham BS, Barnette DJ, Feldman BD: Embryonal rhabdomyosarcoma presenting in an adult $-\mathrm{A}$ case report and discussion of immunohistochemical staining. Am J Dermatopathol 2003, 25:45-52

5. Ulutin C, Bakkal BH, Kuzhan O: A cohort study of adult rhabdomyosarcoma: a single institution experience. World J Med Sci 2008, 3:54-59

6. Kattan J, Culine S, Terrier-Lacombe MJ, Théodore C, Droz JP: Paratesticular rhabdomyosarcoma in adult patients: 16-year experience at institute Gustave-Roussy. Ann Oncol 1993, 4: 871-875

7. Takahashi T, Machida K, Honda N, Hosono M, Kashimada A, Murata O, Osada H, Nishimura K: Adult Embryonal rhabdomyosarcoma in axilla. Radiation Medicine 2003, 21: 135-137 